\title{
Strategic analysis of the potential of bioenergy: outlook for Ukraine
}

\author{
Valentyna Yakubiv \\ Vasyl Stefanyk Precarpathian National \\ University \\ Ivano-Frankivsk, Ukraine \\ yakubiv.valentyna@gmail.com
}

\author{
Iryna Hryhoruk \\ Vasyl Stefanyk Precarpathian National \\ University \\ Ivano-Frankivsk, Ukraine \\ Ira.hryhoruk@gmail.com \\ Nazariy Popadynets* \\ M. I. Dolishniy Institute of Regional \\ Research of NAS of Ukraine \\ Lviv, Ukraine \\ popadynets.n@gmail.com
}

\author{
Yuliia Maksymiv \\ Vasyl Stefanyk Precarpathian National \\ University \\ Ivano-Frankivsk, Ukraine \\ j.maksumiv@gmail.com
}

\begin{abstract}
Modern Ukraine is an attractive investment object for renewable energy development. Favourable natural and climatic conditions and a convenient geographical location create an enabling environment for renewable energy industry, in particular, the significant untapped potential "lies" in agriculture, which has all conditions for economically and environmentally efficient production of liquid and solid biofuels. The trends of energy production from various sources and the development of bioenergy in the world and in Ukraine have been analysed. The complex research of the strategic potential of bioenergy development has been conducted on the basis of economic and statistical methods, PEST-analysis. The results of a sociological survey of existing agricultural enterprises of Ukraine, potential producers of bioenergy, are presented. According to the results of the study, Ukraine has a significant strategic potential for the development of various renewable energy sources, including bioenergy. The necessity and mechanism of estimation of natural and acquired competitive advantages of energy production development from different sources based on technological and economic efficiency of production have been substantiated. The algorithm of investor decision making on the choice of alternative sources in a certain area has been offered on the basis of comparison of technological and economic efficiency of energy production.
\end{abstract}

Keywords-bioenergy, decision making, energy security, investment, PEST analysis, renewable energy sources, strategic potential

\section{INTRODUCTION}

Modern Ukraine is an attractive investment object in the context of the development of renewable energy. Favourable natural and climatic conditions and a convenient geographical location are the main preconditions for business development based on bioenergy, the main source of which is biomass formed as a result of functioning of agrarian enterprises.

At the same time, the European integration processes taking place in Ukraine require the introduction of changes in different levels, such as economic, energy, customs, tax, etc. However, for the achievement of the expected positive results of European integration it is important for Ukraine to be adapted and included to the main economic and social transformations taking place in the countries of the European Union. The current global trend is changes in energy balances. In this aspect the EU countries are dynamically developing. The rapid pace of exhaustion of world oil and gas reserves stimulates the EU countries to actively develop renewable energy. For Ukraine at present, it is urgent to have an active development of the bioenergy sector.

In this research we consider bioenergy as a form of renewable energy derived from biomass, where agriculture is one of the leading sources of biomass feedstock. Therefore, such kind of biomass is called agrobiomass.

Strategic potential of bioenergy in agriculture has been outlined in a number of publications. Y. Voytenko proposes facilitating and restraining factors for the transition to agrobioenergy in Ukraine, and suggests strategies and recommendations to a variety of stakeholders to facilitate this transition [1].

Most of the studies on future actions and strategies concerning bioenergy in Ukraine emphasize on positive trends. Thus Raslavičius et al. summarized mix of policy tools and institutional actions for enhancing bioenergy use [2]. As published by Karpenko et al. the economically justified energy potential of the current biomass waste is about 25 million tons of fuel [3].

However, there are a lot of obstacles. R. Stupen and O. Stupen identify the main problems and conflicts of interest in biofuel sphere, such as a negative impact on food security; increase in prices for food products; competition for energy cultures between the food and energy markets, etc [4]. Thus, most authors agree that full state support is a key for successful development of bioenergy sphere [5].

For Ukraine the battle for its energy safety is an additional issue of importance. Therefore, renewable energy sources development is the decisive matter in the context of overcoming the risks faced by Ukraine country in current conditions [6] and achieving national security. 


\section{THE AIM AND METHOD USED}

The process of defining strategic benchmarks for bioenergy development in Ukraine consists of a set of interconnected stages:

- analysis of global and European trends in the development of renewable energy, in particular bioenergy;

- strategic analysis of the potential of bioenergy development based on agricultural enterprises in Ukraine;

- research of the conceptual foundations of the strategic development of the energy sector;

- substantiation of strategic vectors for bioenergy development in Ukraine.

The calculation-constructive method, grouping, comparison, modelling, forecasting, and algorithmic method were used in the research.

Initial data for the study were statistical data $[7 ; 8 ; 9]$ and documents on strategic development of various countries $[10 ; 11]$.

\section{RESEARCH RESULTS}

Rapid growth of the world economy is accompanied by an increase in energy consumption. Thus, according to Global energy statistical yearbook 2018, over the past seven years, energy consumption in the world has been increasing approximately by $2 \%$ annually (in the Europe - +4,5\%). There is acceleration in energy consumption in $2017(+2.3 \%$ vs. $1.1 \%$ in 2016). One of the main reasons is the growing need for additional energy in these countries due to the active development of the economy. Typological structure of consumed energy shows that oil, coal and gas show major share in consumption (Fig. 1). The share of modern renewables in total final energy consumption has been growing since the 2000s and reached over 10\% in 2017. Renewables-based electricity generation (now one-quarter of total generation) accounted for just over $55 \%$ of the increase in renewables energy use since 2000 , most of which was driven by hydro, wind and bioenergy [7].

Modeling in the Renewables 2018 forecasts, the share of renewables due to global energy demand is expected to be increased by one-fifth in the next five years, finally reaching $12.4 \%$ in 2023 [7]

According to the estimates of O. Dubenska [12], in 2040 contribution of biofuels to the total supply of primary energy in the world will be $10-16 \%$ (in 2012 it was 10\%), the similar indicator for the countries of the European Union (EU) is expected at the level of $13-20 \%$ (in 2012 it was $8 \%$ ), for the USA it is $7-15 \%$ (in 2012 it was $4 \%$ ). O. Dubenska reported that contribution of biofuels to final energy consumption in 2040 is expected at $10-16 \%$ in the world (in 2012 it was $12 \%$ ), in the EU countries it is $11-19 \%$ (in 2012 it was $7 \%$ ), in the USA $-8-17 \%$ (in 2012 it was $5 \%$ ), depending on the development scenario [12].

Data on trends in renewable energy development in the world and in OECD countries indicate that, taking into account the rapid use of exhausting energy resources, developed countries are stably implementing the planned targets for the changes in energy balances. Thus, according to ENERGY 2020 [14] the EU aims to reduce greenhouse gas emissions by at least $20 \%$ by 2020 , increase the share of renewable energy sources to at least $20 \%$ of consumption, and achieve energy savings of $20 \%$ or more.

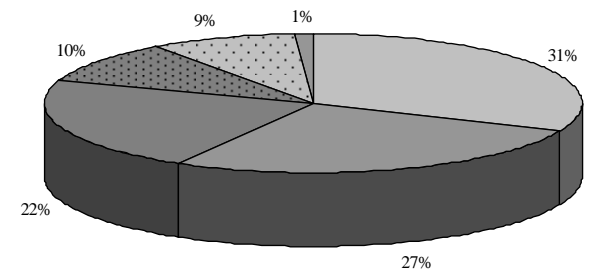

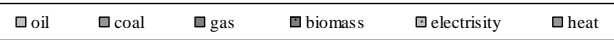

Fig. 1. Relative weight of global energy consumption according to generation sources (including biomass) in 2017 (Word)

Source: Developed by authors based on [13]

All EU countries must also achieve $10 \%$ of renewable energy in the transport sector (mainly due to the potential of liquid biofuel production based on agricultural enterprises). The EU 2030 Framework Program on Climate and Energy includes goals for achieving a more competitive, reliable and stable energy system, and reducing greenhouse gas emissions by 2050 .

The EU's 2030 goals are:

- $40 \%$ cut in greenhouse gas emissions compared to 1990 level;

- at least a $27 \%$ share of renewable energy consumption;

- $\rightarrow$ at least $27 \%$ energy savings compared with the business-as-usual scenario.

To achieve these goals, significant investments in new low carbon technologies, renewable energy, energy efficiency and network infrastructure are required. Since investments are made over the period from 20 to 60 years, a policy that promotes a stable business climate that stimulates low carbon investments should be launched today.

Thus, the analysis of tendencies and perspectives of the development of renewable energy in the world has shown that economically advanced countries are actively implementing strategic plans to stimulate different kinds of renewable energy sources based on opportunities in a particular country, including ones on the basis of agricultural potential.

A. Strategic analysis of the potential of bioenergy development based on agriculture in Ukraine

For Ukraine it is extremely important to intensify the development of renewable energy, including bioenergy. European integration processes require a gradual adaptation to the development trends of the EU. Therefore, at this stage it is crucial to determine the strategic guidelines for the development of this industry.

As we can see from Fig. 2 renewables in the total final energy consumption in Ukraine has $6 \%$ in 2016 p. $(1,3 \%$ in 2000 ), and the world's share of renewables is $18 \%$.

Rather slow development of the renewable energy in Ukraine causes a number of problems related to economic, 
energy, environmental aspects, as well as security and dependence on energy of the supply countries.

According to the Bioenergy Association of Ukraine, the economically feasible current bioenergy potential is about 20 million TOE, and it could reach 42 million TOE in 2050. This is possible due to increased use of corn for biogas production, energy crops cultivation and use of biogas [15].
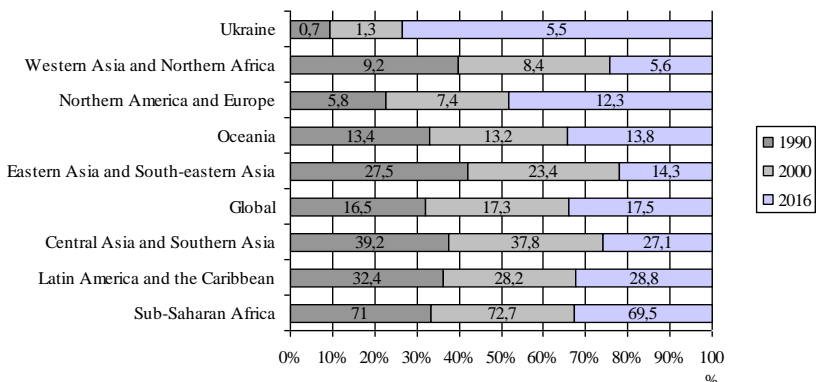

Fig. 2. \% Share (in TFEC) of renewables in the total final energy consumption

Source: developed based on the data of [16]

Therefore, agrarian enterprises are very promising for bioenergy development in Ukraine. There is some steady positive dynamics of the grain crops and sunflower production. According to statistic data, general tendency is an increase in yield, which in 2018 compared to 2000 was 2.6 times for grain corps, 1.9 times for wheat, 1, 9 times - for sunflower. In 2018, a record harvest obtained in Ukraine reached 35.8 million tons ( 78.4 centner / ha) for grain corn and 14.2 million tons (23 centner / ha) for sunflower [17].

Thus, the country has stable high production volumes of main crops with the prospect of further growth, which is a powerful source of various types of agrobiomass.

We should take into account that agrobiomas also is being used in other lines, such as, organic fertilizers in crop production and litter, and feed in livestock production. Therefore, the maximum amount of agrobiomas that can be used to produce energy is generally determined as $30-40 \%$ of the theoretical potential, i.e the total amount of crop production waste [18].

\section{B. Research of conceptual foundations of strategic development of the Renewable Energy Industry in Ukraine}

The PEST-analysis of the prospects for the development of the renewable energy market in Ukraine has shown both the main promising directions as well as the problematic ones (Table 1).

The conducted PEST analysis showed that the most influential factors in the process of formation of renewable energy market in Ukraine are economic factors with a coefficient of influence of 4.32, as well as political - with a coefficient of 3.94. Social factors have the value of 3.88 , and technological - 3.86. The analysis outlined the factors that have a positive and negative impact on the investigated process. Indicators of probability of occurrence and impact score show what factors should be considered first and foremost.
PEST ANALYSIS OF THE RENEWABLE ENERGY MARKET IN UKRAINE

\begin{tabular}{|c|c|c|c|c|}
\hline & Factor & 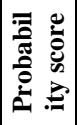 & 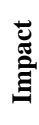 & 萨 \\
\hline \multirow{19}{*}{ 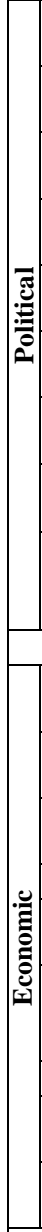 } & $\begin{array}{ll}\text { Changes in legislative regulation of renewable } \\
1 \text { energy market development }\end{array}$ & 0.12 & 4 & 0.48 \\
\hline & \begin{tabular}{|l|l|} 
Legislative regulation for enhancing market \\
2 & development of certain types of renewable sources
\end{tabular} & 0.12 & 4 & 0.48 \\
\hline & \begin{tabular}{|l|l|} 
Establishment of the state targeted assistance to \\
support actors moving to renewable energy
\end{tabular} & 0.06 & 5 & 0.30 \\
\hline & \begin{tabular}{|l|l|l|} 
Introducing tax incentives for producers of \\
renewable energy sources
\end{tabular} & 0.06 & 5 & 0.30 \\
\hline & \begin{tabular}{|l} 
Changing the requirements of environmental \\
5 legislation
\end{tabular} & 0.06 & 3 & 0.18 \\
\hline & \begin{tabular}{|l|l|} 
Signing the economic part of the Association \\
Agreement between the EU and Ukraine
\end{tabular} & 0.10 & 4 & 0.40 \\
\hline & \begin{tabular}{|l|l|}
7 & $\begin{array}{l}\text { Eliminating bureaucratic obstacles to the } \\
\text { development of renewable energy business }\end{array}$
\end{tabular} & 0.08 & 5 & 0,40 \\
\hline & $\begin{array}{ll}\text { Changing the conditions for getting imported } \\
8 \text { traditional energy sources }\end{array}$ & 0.20 & 4 & 0.80 \\
\hline & \begin{tabular}{|l} 
Decentralization of power, administrative reforms \\
and growth of budgetary autonomy of \\
communities
\end{tabular} & 0.20 & 3 & 0.60 \\
\hline & Political factors & 1.00 & $X$ & 3.94 \\
\hline & \begin{tabular}{|l} 
Establishing a stimulating "green tariff" (feed-in \\
tariff) for a wide range of producers
\end{tabular} & 0.06 & 5 & 0.30 \\
\hline & \begin{tabular}{|l}
2 \\
2 Shanging prices for traditional (fossil) energy \\
sources
\end{tabular} & 0.16 & 4 & 0.64 \\
\hline & \begin{tabular}{|l|l|l|}
3 & $\begin{array}{l}\text { Active development of renewable energy in } \\
\text { general }\end{array}$ \\
\end{tabular} & 0.08 & 5 & 0.40 \\
\hline & 4 Enhancing business development & 0.10 & 3 & 0.30 \\
\hline & $\begin{array}{l}\text { Increase in the volume of attracted investments } \\
\text { into the economy }\end{array}$ & 0.10 & 4 & 0.40 \\
\hline & \begin{tabular}{|l}
$\begin{array}{l}\text { Increasing the number of large companies in the } \\
\text { region who are willing to invest in their production } \\
\text { technologies }\end{array}$ \\
\end{tabular} & 0.08 & 5 & 0.40 \\
\hline & 7 The spread of inflationary processes & 0.14 & 5 & 0.70 \\
\hline & \begin{tabular}{|l|l|l} 
Increase in interest rates on loans in national \\
8 currency
\end{tabular} & 0.14 & 5 & 0.70 \\
\hline & \begin{tabular}{|l|l|l|} 
Activation of scientific and entrepreneurial \\
9 cooperation with foreign partners
\end{tabular} & 0.12 & 4 & 0.48 \\
\hline \multirow{6}{*}{ 晃 } & Economic factors & 1.00 & $X$ & 4.32 \\
\hline & \begin{tabular}{|l|l|} 
& $\begin{array}{l}\text { Level of profitability of population (an ability to } \\
\text { switch to self-sufficiency of renewable energy) }\end{array}$ \\
\end{tabular} & 0.20 & 5 & 1.0 \\
\hline & $2 \begin{array}{l}\text { Readiness of population to switch to renewable } \\
\text { energy }\end{array}$ & 0.16 & 3 & 0.48 \\
\hline & \begin{tabular}{|l|l|} 
& Fostering strong public position on the need to \\
move to renewable energy sources
\end{tabular} & 0.16 & 3 & 0.48 \\
\hline & \begin{tabular}{|l|l|} 
Spread of migration processes, including outflow \\
of highly skilled personnel
\end{tabular} & 0.28 & 4 & 1.12 \\
\hline & 5 Growth of social tension & 0.20 & 4 & 0.8 \\
\hline \multirow{7}{*}{ 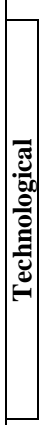 } & Social factors & 1.00 & $X$ & 3.88 \\
\hline & \begin{tabular}{|l} 
Presence of natural and climatic conditions for the \\
1 development of renewable energy
\end{tabular} & 0.3 & 4 & 1.2 \\
\hline & \begin{tabular}{|l} 
Availability of technical and technological \\
capacities for the development of various types of \\
renewable energy
\end{tabular} & 0.2 & 4 & 0.8 \\
\hline & 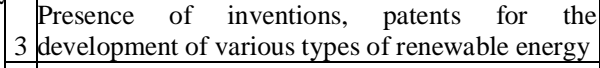 & 0.12 & 3 & 0.36 \\
\hline & \begin{tabular}{|l} 
Availability of powerful scientific potential for \\
renewable energy sources
\end{tabular} & 0.2 & 4 & 0.8 \\
\hline & \begin{tabular}{|l|l|}
5 & Activation of high-tech production \\
\end{tabular} & 0.1 & 3 & 0.3 \\
\hline & 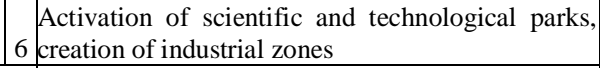 & 0.08 & 5 & 0.4 \\
\hline & Technological factors & 1.00 & $X$ & 3.86 \\
\hline
\end{tabular}

The strategic potential of bioenergy development was also determined on the basis of a sociological survey conducted by interviewing forty five Ukrainian enterprises 
from the agricultural and wood-processing industries that are about to produce bioenergy.

According to the results of the study, $44.4 \%$ of potential renewable energy producers consider that Ukraine has a very high potential for the development of renewable energy sources, and $37.8 \%$ believe that bioenergy market development has a high potential for growth (Fig. 3).
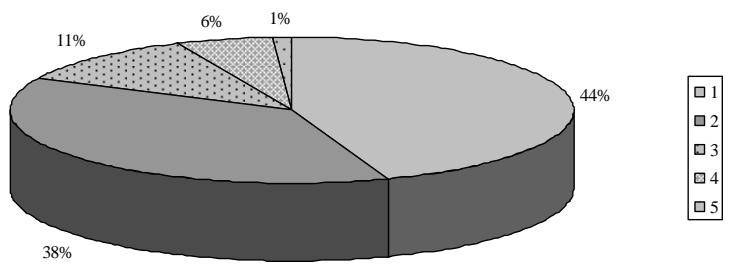

Fig. 3. Assessment of the potential of the renewable energy market development in Ukraine (left) and the solid biofuel market in Ukraine (right) (1 poorly, 5 - very good)

Source: developed based on the data of [11]

Assessing the potential for the development of various types of renewable energy sources, the possible producers determine that solar, wind power and bioenergy offer the greatest potential (Fig. 4).

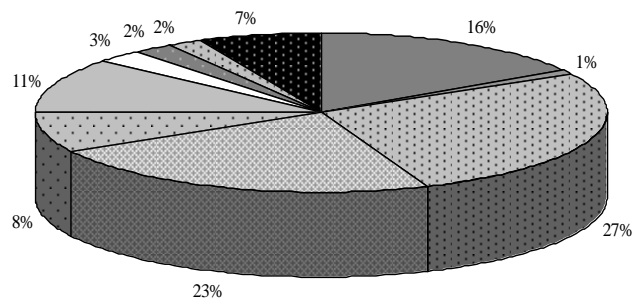

\begin{tabular}{|c|c|c|}
\hline $\begin{array}{l}\text { G biomass energy } \\
\square \text { wind power } \\
\text { Q aerothermal }\end{array}$ & $\begin{array}{l}\square \text { gas from organic waste, ets } \\
\square \text { geothermal power } \\
\square \text { waves and tides }\end{array}$ & $\begin{array}{l}\text { Q solar } \\
\text { Q hydrothermal } \\
\text { Q energy of }\end{array}$ \\
\hline hydroelectric & & \\
\hline
\end{tabular}

Fig. 4. Estimation of the strategic potential of renewable energy sources in Ukraine

Source: developed based on the data of [11]

The results of sociological research have shown that the possible bioenergy producers are positively evaluating Ukraine's strategic potential for the development of this industry, as well as the willingness to enter this new solid biofuel market that is actively developing around the world.

According to $\mathrm{N}$ Hurmak et al. the great benefits of launching this business are evident: there is a constant longterm demand for the end product, even if there are a significant number of competitors in the industry [19].

However, given the fact that this industry requires significant investment, it is important to determine the effectiveness of such investments. The level of profitability and return on investment depends on the level of profitability of the main activity, and this indicator, in turn, depends on the cost of production.

The level of profitability of energy production from different sources will be different as it is determined by technological differences in production. But in this case we are talking about competition of substitute goods. However, according to Saura et at the same time there will be a different level of profitability of energy production from the same renewable source in different areas [20].

The profitability of biofuel production will be influenced by the availability of the producer's own agricultural biomass, the yield of agricultural crops, the waste from processing, which is the basis for the production of biofuels, etc.

In order to maximize the return on investment in renewable energy sources, all available competitive advantages need to be exploited. To do this, we propose an algorithm for decision making on the choice of renewable energy source in a particular area:

1. Evaluation of all potential sources of renewable energy production in the region (wind energy, solar energy, hydropower, geothermal energy, bioenergy, etc.) (among technologically possible);

2. Comparison of the technological efficiency (Et) of different sources of renewable energy production in the region $\left(\mathrm{Et}_{\mathrm{w}}-\right.$ Wind Power, $\mathrm{Et}_{\mathrm{s}}-$ Solar Power, $_{\mathrm{E}} \mathrm{t}_{\mathrm{h}}-\mathrm{Hydropower}_{\text {, }}$ $\mathrm{Et}_{\mathrm{gt}}-$ Geothermal Energy,Et $\mathrm{b}_{\mathrm{b}}-$ Bioenergy, etc.)

$$
\begin{array}{ll}
\mathrm{Et}_{\mathrm{w}} \geq \mathrm{Et}_{\mathrm{s}} \text { or } & \mathrm{Et}_{\mathrm{s}} \geq \mathrm{Et}_{\mathrm{w}} \\
\mathrm{Et}_{\mathrm{h}} \geq \mathrm{Et}_{\mathrm{s}} \text { or } & \mathrm{Et}_{\mathrm{s}} \geq \mathrm{Et}_{\mathrm{h}} \\
\mathrm{Et}_{\mathrm{gt}} \geq \mathrm{Et}_{\mathrm{s}} \text { or } \quad \mathrm{Et}_{\mathrm{s}} \geq \mathrm{Et}_{\mathrm{gt}} \\
\mathrm{Et}_{\mathrm{b}} \geq \mathrm{Et}_{\mathrm{s}} \text { or } \quad \mathrm{Et}_{\mathrm{s}} \geq \mathrm{Et}_{\mathrm{b}}
\end{array}
$$

3. Comparison of the economic efficiency (Ee) of different sources of renewable energy production in the region $\left(\mathrm{Ee}_{\mathrm{w}}-\right.$ wind power, $\mathrm{E}_{\mathrm{sp}}-$ solar power, $\mathrm{Ee}_{\mathrm{h}}-$ hydropower, $\mathrm{Ee}_{\mathrm{gt}}-$ geothermal energy, $\mathrm{Ee}_{\mathrm{b}}-$ bioenergy, etc.)

$$
\begin{array}{ll}
E_{\mathrm{w}} \geq \mathrm{Ee}_{\mathrm{s}} \text { or } & \mathrm{Ee}_{\mathrm{s}} \geq \mathrm{Ee}_{\mathrm{w}} \\
\mathrm{Ee}_{\mathrm{g}} \geq \mathrm{Ee}_{\mathrm{s}} \text { or } \quad & \mathrm{Ee}_{\mathrm{s}} \geq \mathrm{Ee}_{\mathrm{g}} \\
\mathrm{Ee}_{\mathrm{gt}} \geq \mathrm{Ee}_{\mathrm{s}} \text { or } \quad & \mathrm{Ee}_{\mathrm{s}} \geq \mathrm{Ee}_{\mathrm{gt}} \\
\mathrm{Ee}_{\mathrm{b}} \geq \mathrm{Ee}_{\mathrm{s}} \text { or } \quad \mathrm{Ee}_{\mathrm{s}} \geq \mathrm{Eet}_{\mathrm{b}}
\end{array}
$$

4. Determination of the natural competitive advantages related to the technological efficiency of the production of energy from renewable sources $(\mathrm{Et})$ and the acquired competitive advantages associated with the economic efficiency of the production of energy from renewable sources (Ee).

5. Comprehensive evaluation of the investment project with the definition of indicators: Net Present Value (NPV), Internal Rate of Return (IRR), Payback Time (PBT) which is identified in the research [21].

6. The decision to choose the most efficient and economically feasible type of source of renewable energy production.

A significant competitive advantage for biomass energy production is that this type is not directly related to natural conditions. It depends a lot on the presence of agricultural and wood-processing enterprises, which makes it more economically and technologically promising 


\section{CONCLUSIONS}

Economically advanced countries aim to achieve 50\% renewable energy use in the energy balance according to their development strategies. This is due to the exhaustion of existing traditional energy resources, on the one hand, and to the rapid growth of the economy and the growth of energy demand for production purposes, on the other hand.

Analysis of global and domestic trends in renewable energy showed that comparing to the developed countries Ukraine is not so successful in the renewable energy sector, but it has considerable potential, especially in bioenergy, and necessary resources for this. Strategic vectors for bioenergy development have been outlined.

In order to strengthen Ukraine's position in the world market of renewable energy and maximize the effective use of available potential, the following steps should be taken:

1) to develop a road map for the most promising types of renewable energy sources, namely bioenergy, based on agricultural biomass;

2) to implement the mechanism of state incentives for the development of bioenergy in accordance with a substantiated roadmap and technological and environmental feasibility of its production on the basis of agricultural enterprises.

Thus, a comprehensive study of the strategic preconditions for the development of renewable energy on the basis of agricultural enterprises showed the existence of a certain strategic potential of various types of renewable energy sources in Ukraine. Algorithm for decision making on the choice of renewable energy source has been suggested.

The results of analysis have shown that there are some difficulties with the economic and legal regulation of the market for renewable sources in Ukraine. Therefore, the specification of the economic and legal framework for regulating the activities of business entities that produce renewable energy should be included in the concept of the renewable energy development in Ukraine.

\section{REFERENCES}

[1] Y. Voytenko, "Pathways for agro-bioenergy transition in Ukraine", Biofuels, Bioproducts and Biorefining, vol. 6, no. 2, pp. 124-134, 2012. [in Ukrainian].

[2] L. Raslavičius, A. Grzybek, and V. Dubrovin, "Bioenergy in UkrainePossibilities of rural development and opportunities for local communities", Energy Policy, vol. 39, no. 6, pp. 3370-3379, 2011.

[3] V. Karpenko, O. Burliai, and I. Mostoviak, "Economy's agricultural sector potential in Ukrainian energy self-sufficiency forming", Economic Annals-XXI, vol. 155, no. 11-12, pp. 55-58, 2015. [in Ukrainian]

[4] R. Stupen, and O. Stupen, "Formation of energy resources potential of rural territories" Engineering for Rural Development, no. 17, pp. $1639-1643,2018$

[5] M. Myronenko, O. Polova, A. Prylutskyi, and O. Smoglo, "Financia and economic aspects of bioenergy development in the context of providing energy independence of Ukraine", Problems and Perspectives in Management, vol. 15, no. 4, pp. 243-253, 2017. [in Ukrainian].

[6] V. Yakubiv, O. Panukhnyk, S. Shults, Y. Maksymiv, I. Hryhoruk, N. Popadynets, R. Bilyk, Y. Fedotova, and I. Bilyk, Application of Economic and Legal Instruments at the Stage of Transition to Bioeconomy. In: Advances in Artificial Intelligence, Software and Systems Engineering, Proceedings of the AHFE 2019, Washington D.C., 2019.

[7] Statistical Yearbook, International energy agency. Sustainable development goal 7, 2016. [Online]. Available: https://www.iea.org/sdg/renewables/

[8] Global energy statistical yearbook, 2018. [Online]. Available: https://yearbook.enerdata.net/total-energy/world-consumptionstatistics.html

[9] The Energy Progress Report, 2019. [Online]. Available: http://trackingsdg7.esmap.org/results

[10] Energy Roadmap 2050, Communication from the commission to the European parliament, the Council, the European economic and social committee and the Committee of the regions, 2011. [Online]. Available: http://eur-lex.europa.eu/legal-content

[11] Energy of Ukraine, Electricity production in Ukraine for 12 months in 2016 decreased by $1.8 \%$, 2017. [Online]. Available: http://uaenergy.com.ua/post/28082/proizvodstvo-elektroenergii-vukraine-za-12-mes-2016-g/ [in Ukrainian].

[12] O. Dubenska, What awaits the world economy, Economic truth, 2015. [Online]. Available: https://www.epravda.com.ua/publications/2015/04/24/539599/Boiene rgetika

[13] Global energy statistical yearbook, 2018. [Online]. Available: https://yearbook.enerdata.net/total-energy/world-consumptionstatistics.html

[14] Energy 2020, A strategy for competitive, sustainable and secure energy. Communication from the commission to the European parliament, the Council, the European economic and social committee and the Committee of the regions, 2010. [Online]. Available: https://eur-lex.europa.eu/legalcontent/EN/ALL/?uri=celex:52010DC0639

[15] Y. Oharenko, and O. Aliieva, Transition of Ukraine to the Renewable Energy by 2050: Publishing house “Art Book" Ltd, 2017. [Online]. Available: https://ua.boell.org/sites/default/files/transition_of_ukraine _to_the_renewable_energy_by_2050_1.pdf [in Ukrainian].

[16] The Energy Progress Report, 2019. [Online]. Available: http://trackingsdg7.esmap.org/results

[17] Crop production in Ukraine 2017, Statistical yearbook by SSSU, 2018. [Online]. Available: http://www.ukrstat.gov.ua/

[18] UABio Position Paper no. 7, Prospects for the use of agricultural residues for energy production in Ukraine, 2017. [Online]. Available: http://uabio.org/img/files/docs/Position-paper-UABIO-7-EN.pdf [in Ukrainian].

[19] N. Hurmak, and V. Yakubiv, "Efficiency of Intermediary Activity of Agricultural Enterprises: Methods and Assessment Indicators", Bulgarian Journal of Agricultural Science, vol. 23, no. 5, pp. 712716, 2017.

[20] S. Saura, C. Esteguil, C. Mouton, and M. Rodriguez-Freire, Ecological Indicators - Network analysis to assess landscape connectivity trends, Application to European forests (1990-2000). Ecological Indicators, vol. 11, no. 2, pp. 407-416, 2011.

[21] M. Salerno, F. Gallucci, L. Pari, I. Zambon, D. Sarri and A. Colantoni, "Costs-benefits analysis of a small scale biogas plant and electric energy production", Bulgarian Journal of Agricultural Science, vol. 23, no. 3, pp. 357-362, 2017. 